\title{
Analisis dan Optimasi Pengaruh Suhu Gas Umpan Pada Kinerja Acid Gas Removal Unit
}

\section{Analysis and Optimization on the Effect of Feed Gas Temperature on the Performance of Acid Gas Removal Unit}

Iwan Febrianto $^{1^{*}}$, Nelson Saksono ${ }^{2}$

${ }^{1,2}$ Departemen Teknik Kimia, Fakultas Teknik, Universitas Indonesia

\begin{abstract}
ARTICLE INFO
Article history:

DOI:

$\underline{10.30595 / p s p f s . v 1 i .136}$

Submitted:

June 25, 2021

Accepted:

July 12, 2021

Published:

Oct 31,2021

Keywords:

AGRU, Reconstruction,

ABSTRACT

The Gas Gathering Station (GGS) in field X processes gas from 16 (sixteen) wells before being sent as selling gas to consumers. The sixteen wells have decreased in good pressure since 2011, thus affecting the performance of the Acid Gas Removal Unit (AGRU). The GGS consists of 4 (four) main units, namely the Manifold Production/ Test, the Separation Unit, the Acid Gas Removal Unit (AGRU), the Dehydration Unit (DHU). The AGRU facility in field X is designed to reduce the acid gas content of $\mathrm{CO} 2$ by $21 \mathrm{~mol} \%$ with a feed gas capacity of 85 MMSCFD. A decrease in reservoir pressure caused an increase in the feed gas temperature and an increase in the water content of the well. Based on the reconstruction of the design conditions into the simulation model, the amine composition consisting of MDEA 0.3618 and MEA $0.088 \mathrm{wt}$ fraction to obtain the percentage of $\mathrm{CO} 2$ in the $5 \% \mathrm{~mol}$ sales gas. The increase in feed gas temperature up to $146 \mathrm{~F}$ caused foaming due to condensation of heavy hydrocarbon fraction, so it was necessary to modify it by adding a chiller to cool the feed gas to become $60 \mathrm{~F}$. Based on the simulation, the flow rate of gas entering AGRU could reach 83.7 MMSCFD. There was an increase in gas production of 38.1 MMSCFD and condensate of 1,376 BPD. Economically, the addition of a chiller modification project was feasible with the economical parameters of NPV US\$ $132,000,000$, IRR $348.19 \%$, POT 0.31 year and PV ratio 19.06.
\end{abstract} Foaming, Chiller, Economy
This work is licensed under a Creative Commons Attribution 4.0 International License.

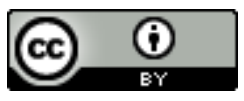

Corresponding Author:

Iwan Febrianto

Departemen Teknik Kimia, Fakultas Teknik, Universitas Indonesia

Email: iwan.febrianto@ui.ac.id

\section{PENDAHULUAN}

Pada Lapangan X terdapat fasilitas Stasiun Pengumpul Gas (SPG) yang mengolah gas dari 16 (enam belas) sumur produksi dengan kapasitas gas umpan sebesar 85 MMSCFD pada suhu gas pada separator $105 \mathrm{~F}$ dan tekanan 800 psig dengan kandungan gas $\mathrm{CO}_{2} 21 \%$ mol. Fasilitas proses di SPG X terdiri atas Manifold Produksi / Tes, Unit Separasi, Acid Gas Removal Unit (AGRU) dan Dehidration Unit (DHU). Fluida dari sumur menuju manifold dan dipisahkan cairannya pada HP Separator yang beroperasi pada tekanan 775 psig dan suhu $91 \mathrm{~F}$, selanjutnya menuju HP Scrubber sebelum menuju ke AGRU. Sweet Gas dari AGRU akan dikirim ke DHU untuk mencapai kadar air 7 lb/MMSCFD. Cairan dari HP Separator menuju ke MP Separator yang beroperasi pada tekanan 200 psig selanjutnya menuju ke LP Separator yang beroperasi pada tekanan 75 psig. Cairan yang dihasilkan selanjutnya dikirim ke Tangki Kondensat. Gas dari MP Separator dan LP Separator digunakan untuk fuel gas. (Deskripsi Proses, 2005).

Acid Gas Removal Unit (AGRU) menggunakan larutan aMDEA licensor BASF untuk menurunkan kandungan $\mathrm{CO}_{2}$ menjadi $5 \%$ mol. Kondisi aktual dengan semakin lama berproduksi, reservoir akan mengalami penurunan tekanan reservoir/tubing, dan peningkatan produksi air yang menyebabkan kenaikan suhu pada gas umpan yang 
ditunjukan pada Gambar 1 dan perubahan komposisi fluida dari reservoir sehingga AGRU eksisting hanya beroperasi 40\% dari kapasitas desain gas umpan 85 MMSCFD karena terjadinya Foaming. Kondensasi fraksi berat dari gas umpan mempunyai suhu yang lebih panas dari pada larutan amine yang masuk dapat menyebabkan Foaming yang akan berkibat pada losses amine dan shutdown plant. Kenaikan suhu absorber juga akan menyebabkan berkurang efektifitas absorbsi $\mathrm{CO}_{2}$ dan $\mathrm{H}_{2} \mathrm{~S}$ oleh larutan amine.

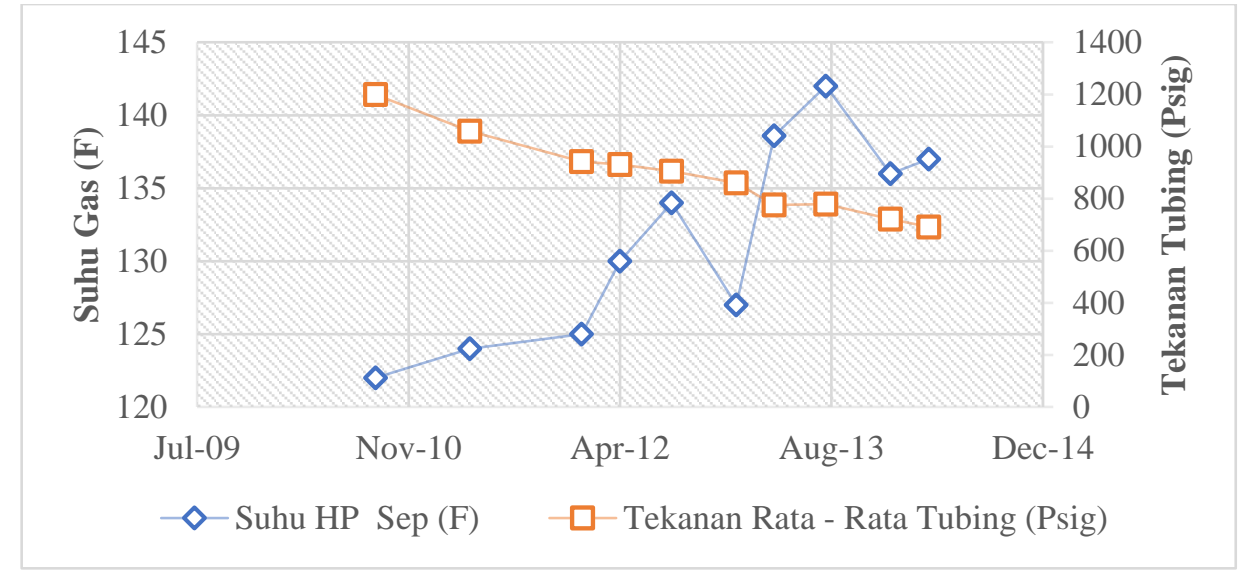

Gambar 1. Pengaruh Penurunan Tekanan Reservoir terhadap Suhu Gas

Dalam paper ini akan dilakukan pemodelan simulasi rekonstruksi menggunakan perangkat lunak UNISIM sesuai desain untuk mendapatkan campuran MDEA dengan activator MEA, kemudian dilakukan simulasi sensitivitas AGRU dengan perubahan tekanan dan suhu gas umpan, optimasi suhu gas umpan serta menghitung keekonomian proyek untuk melakukan modifikasi fasilitas eksisting sehingga AGRU dapat beroperasi optimal.

\section{Tinjauan Teoritis}

Teknologi penghilangan $\mathrm{CO}_{2}$ dan kandungan sulfur dari sour gas pada dasarnya terdiri dari solvent absorption, solid adsoption, direct conversion dan membrane. Pada teknologi solvent absorption menggunakan generic amine yaitu primary (MEA, DGA), secondary (DEA, DIPA), tertiary (TEA, MDEA). Larutan MDEA digunakan pada konsentrasi $30-50 \%$ berat dalam air. Acid gas loading tidak terbatas biasanya $0.7-0.8$ mol asam per mol amine. Sehingga dapat mengurangi jumlah sirkulasi amine (energi pompa berkurang). MDEA tidak mudah terdegradasi baik panas maupun kimia dan mempunyai panas reaksi dengan $\mathrm{H}_{2} \mathrm{~S}$ yang rendah. (Maddox et al., 1998) menyarankan bahwa MDEA dapat digunakan sebagai non selektif larutan untuk menghilangkan $\mathrm{H}_{2} \mathrm{~S}$ dan $\mathrm{CO}_{2}$, atau dapat digunakan sebagai selektif pelarut yang mana akan menghilangkan $\mathrm{H}_{2} \mathrm{~S}$ daripada $\mathrm{CO}_{2}$. (Maddox et al., 1998) menyatakan bahwa selektifitas MDEA dipengaruhi oleh:

1. Suhu : suhu yang lebih rendah akan meningkatkan selektifitas

2. Tekanan : tekanan yang lebih rendah akan meningkatkan selektifitas

3. Rasio $\mathrm{CO}_{2} / \mathrm{H}_{2} \mathrm{~S}$ : semakin tinggi akan mendukung selektifitas

MDEA adalah amine superior karena laju korosi dan laju degradasi yang rendah menghasilkan kemampuan penggunaan konsentrasi larutan tinggi (Polasek dan Bullin, 2006). Loading MDEA secara teoritis 1 mol gas asam / mol amine (Kohl, 1999). Hal ini membuat lebih menarik untuk penghilangan $\mathrm{CO}_{2}$ jika dapat mengatasi laju reaksi MDEA yang rendah dengan $\mathrm{CO}_{2}$. Proses penyerapan $\mathrm{CO}_{2}$ oleh MDEA harus ditingkatkan dengan menambahkan aktivator (Arkema Co., 2000). Amine seperti methanolamine (MEA), diethanolamine (DEA) dan piperazine (PZ) telah digunakan sebagai aktivator untuk campuran MDEA untuk meningkatkan laju reaksi. Campuran Pz / MDEA menyerap $\mathrm{CO}_{2}$ lebih cepat daripada monoetanolamina (MEA) atau diethanolamine (DEA) dicampur dengan MDEA pada kesamaan konsentrasi (Bishnoi, 2002). Berikut ditunjukan Tabel 1. konstanta reaksi pada larutan amine. 
Tabel 1. Konstanta Reaksi Amine pada Penyerapan $\mathrm{CO}_{2}$

(Optimized Treating Inc., 2008)

\begin{tabular}{cc}
\hline Amine & Konstanta Reaksi (L/mol.s) \\
\hline MEA & 6000 \\
DGA & 4500 \\
DEA & 1300 \\
DIPA & 100 \\
Piperazine & 59000 \\
MMDEA & 7100 \\
MDEA & 4 \\
\hline
\end{tabular}

\section{METODE PENELITIAN}

Penelitian dilakukan menggunakan simulasi proses mengikuti tahapan alogaritma seperti pada Gambar 2.

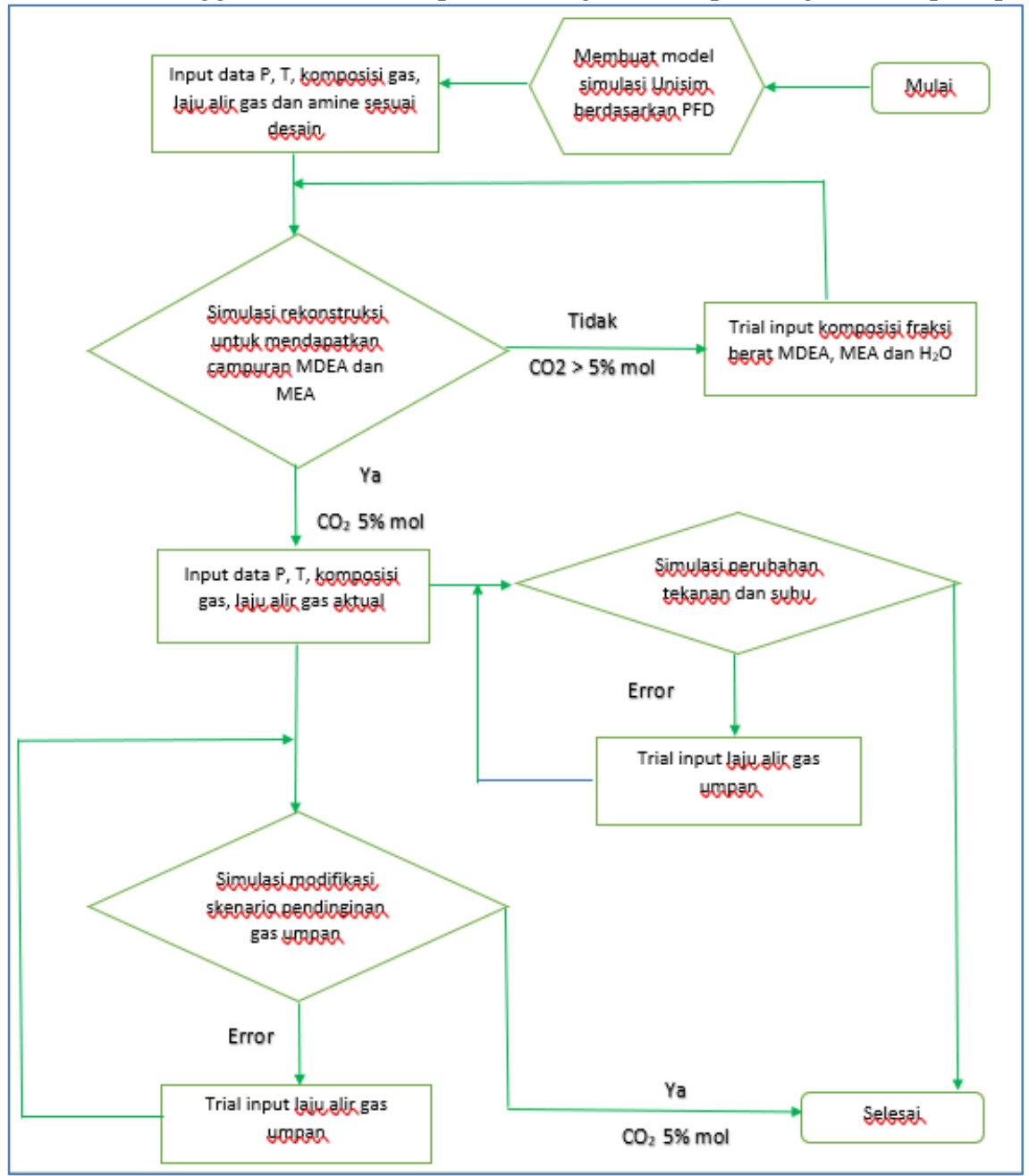

Gambar 2. Alogaritma Simulasi Proses

\section{HASIL DAN PEMBAHASAN}

\section{Simulasi Rekonstruksi}

Pemodelan simulasi rekonstruksi desain menggunakan data gas umpan pada AGRU dengan parameter operasi sesuai dengan data desain. Kemudian setelah didapatkan model rekonstruksi dilanjutkan dengan simulasi sesuai dengan kondisi aktual. Perbedaan data desain dan aktual sebagai parameter masukan dalam simulasi ditunjukan dalam Tabel 2. 


\begin{tabular}{lrc}
\multicolumn{3}{c}{ Tabel 2. Data Desain dan Aktual Gas Umpan } \\
\hline \multicolumn{1}{c}{ Parameter } & \multicolumn{1}{c}{ Desain } & Aktual \\
\hline Name & \multicolumn{1}{c}{ FG } & FG \\
\hline Vapour Fraction & 1.0 & 1.0 \\
Temperature [F] & 83.2 & 140.6 \\
Pressure [psig] & 650.0 & 650.0 \\
Molar Flow [MMSCFD] & 85.0 & 86.0 \\
Mass Flow [lb/hr] & 221049.5 & 228105.0 \\
Comp Mole Frac $\left(\mathrm{CO}_{2}\right)$ & 0.2100 & 0.2105 \\
Comp Mole Frac $\left(\mathrm{H}_{2} \mathrm{~S}\right)$ & $0.00 \mathrm{E}+00$ & $1.80 \mathrm{E}-05$ \\
\hline
\end{tabular}

Pemodelan pada perangkat lunak UNISIM sesuai dengan Process Flow Diagram (PFD) pada kondisi desain ditunjukan pada Gambar 3.

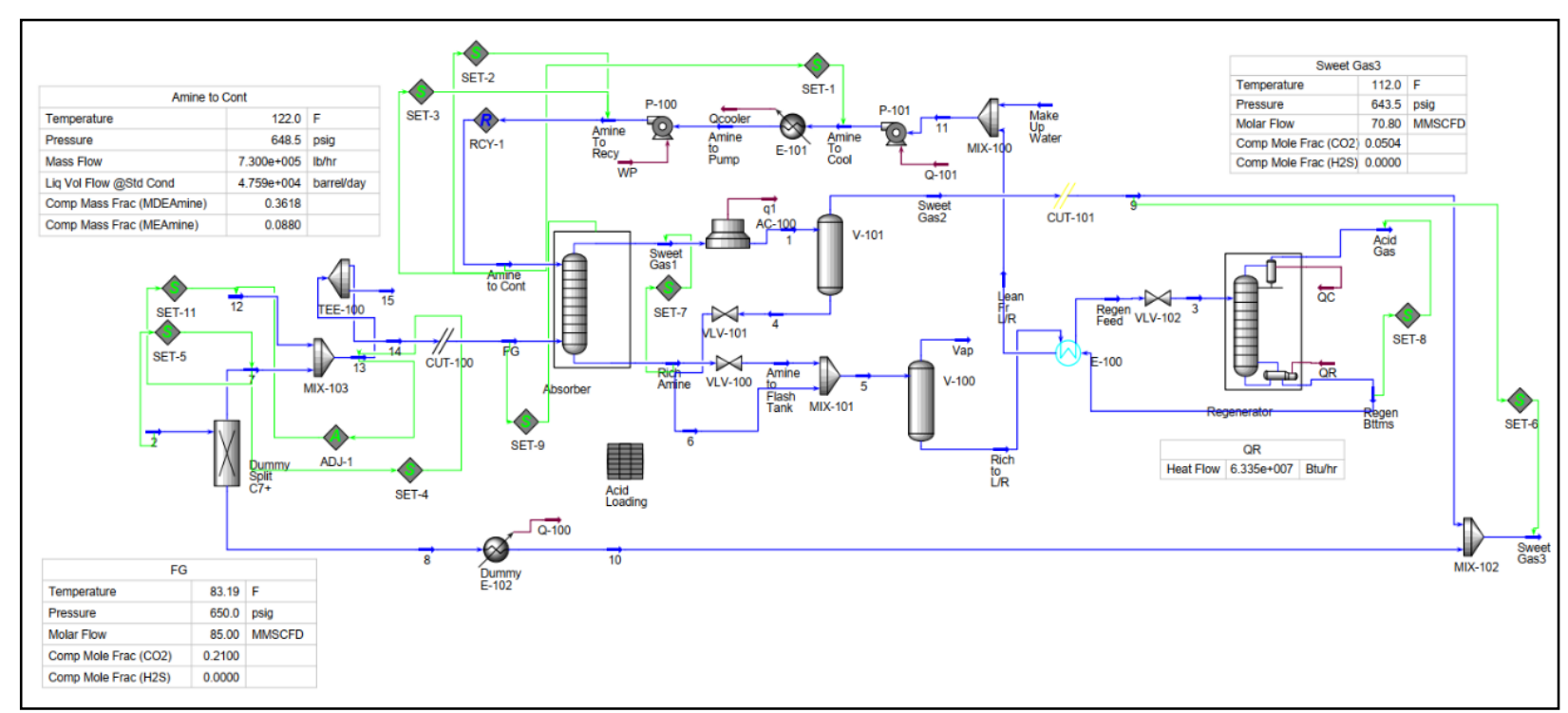

Gambar 3. Model PFD Kondisi Desain

Berdasarkan rekonstruksi simulasi proses didapatkan hasil campuran amine yaitu MDEA 0,3618 dengan activator MEA 0,088 fraksi berat untuk mendapatkan kandungan $\mathrm{CO}_{2}$ pada gas jual sebesar 5\% mol dengan laju alir lean amine sesuai desain. Dari model rekonstruksi tersebut dilanjutkan simulasi kondisi aktual dengan adanya kenaikan suhu, kenaikan laju alir dan perubahan komposisi $\mathrm{CO}_{2}$ dan $\mathrm{H}_{2} \mathrm{~S}$ gas umpan didapatkan kandungan $\mathrm{CO}_{2}$ pada gas jual mengalami kenaikan yaitu menjadi $6.43 \%$ mol dibandingkan kondisi desain. Dengan kondisi tersebut maka produk sales gas tidak memenuhi spesifikasi dengan $\mathrm{CO}_{2} \leq 5 \%$ mol.

\section{Sensitivitas Tekanan Gas Umpan}

Simulasi sensitivitas dilakukan pada laju alir gas umpan 70 MMSCFD karena terkait dengan konvergennya simulator UNISIM dalam studi kasus ini. Perubahan tekanan gas umpan terhadap hasil $\mathrm{CO}_{2}$ dan $\mathrm{H}_{2} \mathrm{~S}$ dalam gas jual ditunjukan pada Gambar 4. Perubahan tekanan gas umpan secara aktual operasi harus mempertimbangkan tekanan gas jual minimal sesuai Perjanjian Jual Beli Gas dan tekanan desain peralatan. 


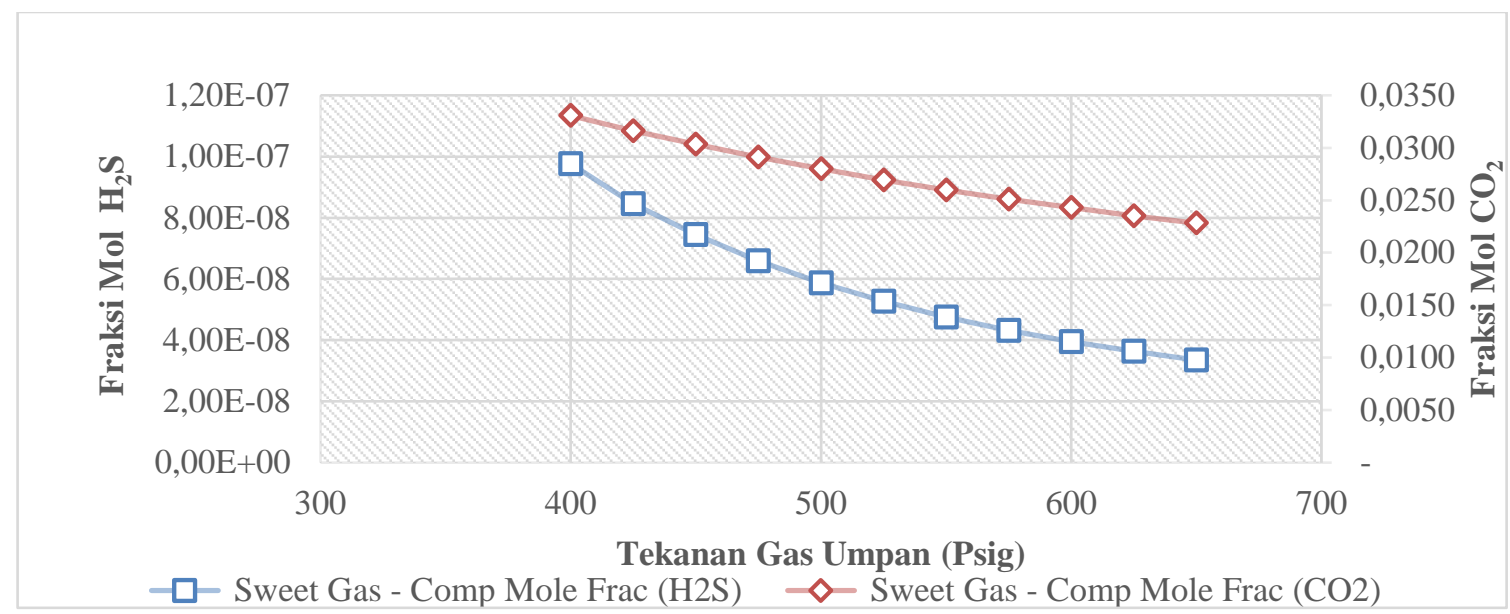

Gambar 4. Sensitivitas Tekanan Gas Umpan

Pengaruh tekanan absorber yang semakin besar akan meningkatkan efisiensi absorbsi sehingga kandungan asam dalam gas jual $\left(\mathrm{CO}_{2}\right.$ dan $\left.\mathrm{H}_{2} \mathrm{~S}\right)$ akan semakin rendah seperti ditunjukan pada Gambar 4. Pengurangan tekanan absorber akan meningkatkan kandungan asam karena terjadi peningkatan volatilitas komponen (J. Park, S. Yoon, S.-Y Oh et al., 2020). Pengurangan tekanan berkontribusi dalam mengurangi tekanan parsial $\mathrm{CO}_{2}$ dalam gas umpan dan akibatnya menurunkan laju reaksi dengan amine, yang menurunkan efisiensi penghilangan $\mathrm{CO}_{2}$ (A.Y. Ibrahim et al., 2014).

\section{Sensitivitas suhu gas umpan}

Dengan berjalannya waktu produksi suhu gas umpan pasti akan mengalami perubahan dari kondisi desain, sehingga suhu gas umpan AGRU harus menjadi pertimbangan dalam desain berdasarkan forecast produksi.

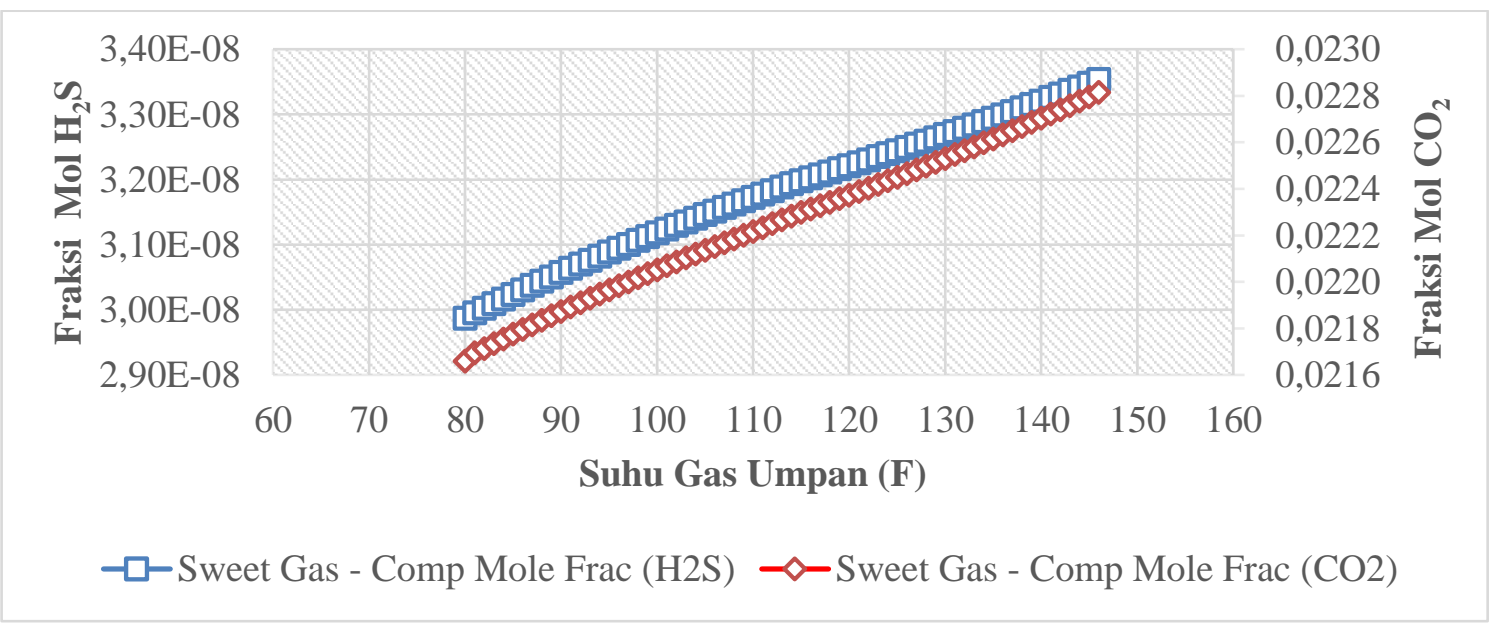

Gambar 5. Sensitivitas Suhu Gas Umpan

Berdasarkan Gambar 5. bahwa semakin tinggi suhu gas umpan akan menghasilkan gas jual dengan kandungan asam yang semakin tinggi. Kondensasi hidrokarbon pada absorber dapat dihindari dengan menjaga suhu lean amine paling sedikit $5{ }^{\circ} \mathrm{C}$ diatas hidrokarbon dew point (GPSA-1998). Suhu gas umpan akan mempengaruhi kondensasi fraksi berat hidrokarbon sehingga pada operasi AGRU akan terjadi foaming. Hidrokarbon fraksi berat yang terbawa oleh gas umpan akibat suhu yang tinggi akan terlarut dalam amine dan tersirkulasi melewati stripper, yang akan menyebabkan gangguan pada pompa lean amine sehingga dapat terjadi shutdown plant. Suhu lean amine yang masuk ke absorber adalah $122 \mathrm{~F}$ sehingga suhu gas umpan maksimal adalah $113 \mathrm{~F}$ untuk menghindari terjadinya foaming.

\section{Modifikasi penambahan peralatan}

Dengan kenaikan suhu gas umpan kondisi aktual plant hanya dapat beroperasi pada laju alir gas umpan 40 MMSCFD dari kapasitas desain 85 MMSCFD karena terjadi foaming pada unit AGRU. Foaming terjadi karena adanya hidrokarbon fraksi berat yang terlarut dalam sirkulasi amine. Berdasarkan simulasi aktual gas umpan 40 MMSCFD didapatkan fraksi mol $\mathrm{CO}_{2}$ dalam gas jual sebesar 0,0018 dan liquid kondensat 931 bpd dengan RVP 13,7 psia. Terdapat 4 (empat) alternatif modifikasi untuk menurunkan suhu gas umpan yang ditunjukan pada Tabel 3. 
Tabel 3. Kondisi Aktual dan Alternatif Modifikasi

\begin{tabular}{lrrrrr}
\hline \multicolumn{1}{c}{ Parameter } & $\begin{array}{c}\text { Aktual } \\
\text { Operasi }\end{array}$ & Chiller & $\begin{array}{c}\text { Air } \\
\text { Cooler }\end{array}$ & $\begin{array}{c}\text { Cooling } \\
\text { Water }\end{array}$ & JT Valve \\
\hline $\begin{array}{l}\text { Gas Umpan Outlet Separator } \\
\text { (MMSCFD) }\end{array}$ & 40 & 84.7 & 79.8 & 80.1 & 83.7 \\
Suhu Gas Umpan Outlet Separator & 146 & 146 & 146 & 146 & 146 \\
(F) & & & & & \\
Gas Umpan Inlet AGRU (MMSCFD) & 39.99 & 83.7 & 79.56 & 79.71 & 83.45 \\
Suhu Gas Umpan Outlet Pendingin & 140.6 & 60 & 113 & 95 & 103.7 \\
(F) & & & & & \\
Suhu Gas Umpan Inlet AGRU (F) & 140.6 & 81 & 113 & 95 & 113 \\
\% Mol CO Inlet AGRU & 21.05 & 21.21 & 21.11 & 21.14 & 21.11 \\
\% Mol CO Outlet AGRU & 0.18 & 5 & 5.11 & 5.42 & 4.99 \\
Gas Jual (MMSCFD) & 31.35 & 69.43 & 65.95 & 66.37 & 69.09 \\
Kondensat (BPD) & 931 & 2307 & 1856 & 1909 & 1946 \\
RVP Kondensat (Psia) & 13.7 & 15 & 13.5 & 13.6 & 13.5 \\
\hline
\end{tabular}

Berdasarkan Tabel 3. Dapat dilihat simulasi kondisi aktual dan alternatif modifikasi untuk menurunkan suhu gas umpan. Kondisi aktual hanya dapat beroperasi dengan gas umpan 40 MMSCFD karena adanya kenaikan suhu dari sumur menjadi $146 \mathrm{~F}$ yang menyebabkan terjadinya foaming. Alternatif pendinginan yang paling optimal menggunakan chiller sehingga suhu gas umpan dapat didinginkan mencapai $60 \mathrm{~F}$ dan masuk absorber sesuai dengan suhu desain $81 \mathrm{~F}$ yang menghasilkan penambahan produksi gas dan kondensat terbanyak diantara alternatif yang lain. Delta suhu antara amine dijaga diatas $5{ }^{\circ} \mathrm{C}$ gas umpan (GPSA-1998) agar tidak terjadi kondensasi fraksi berat yang menyebabkan foaming.

\section{Keekonomian modifikasi}

Perhitungan CAPEX berdasarkan harga kontrak tahun sebelumnya yang dikonversi dengan pendekatan Chemical Engineering Capital Index (CEPCI) ke tahun 2021 ditunjukan pada Tabel 4.

Tabel 4. Perhitungan Biaya Peralatan Utama

\begin{tabular}{cllcrr}
\hline No & Peralatan & \multicolumn{1}{c}{ Spesifikasi } & Volume (Ea) & Harga Satuan (US\$) & Harga Total (US\$) \\
\hline 1 & $\begin{array}{l}\text { Gas/Gas } \\
\text { Exchanger }\end{array}$ & $2.25 \mathrm{MMBTU} / \mathrm{Hr}$ & 1 & $308,464.56$ & $308,464.56$ \\
2 & $\begin{array}{l}\text { Chiller } \\
\text { Package }\end{array}$ & 7.55E6 & 1 & $2,091,756.25$ & $2,091,756.25$ \\
& Total & & & & $2,400,220.81$
\end{tabular}

Dari harga peralatan utama dilakukan perhitungan total CAPEX berdasarkan Plant Cost Factor (Chemical Engineering Economics, 2013) yang ditunjukan pada Tabel 5.

\section{Tabel 5. Total CAPEX}

\begin{tabular}{clrc}
\hline No & \multicolumn{1}{c}{ Komponen } & Plant Cost Factor & Biaya US\$ \\
\hline $\mathbf{1}$ & Manajemen Proyek, Engineering dan & & \\
& Konstruksi : & & 720,066 \\
& Konstruksi dan Engineering & 0.3 & 240,022 \\
& Kontraktor Fee & 0.1 & 360,033 \\
& Kontigensi & 0.15 & 120,011 \\
$\mathbf{2}$ & Persiapan Lokasi, Civil dan Bangunan: & & 240,022 \\
& Penyiapan lahan & 0.05 & 120,011 \\
& Lingkungan & 0.1 & 168,015 \\
& Bangunan & 0.05 & $2,400,221$ \\
\hline
\end{tabular}




\begin{tabular}{lrrr} 
Perpipaan & & 0.15 & 360,033 \\
Elektrikal & 0.1 & 240,022 \\
Instrumen & 0.1 & 240,022 \\
Utilities & 0.3 & 720,066 \\
Insulasi & 0.02 & 48,004 \\
Painting, fire proofing dan safety $\quad$ Total Plant Cost & 0.02 & 48,004 \\
\multicolumn{2}{c}{ Commisioning dan Performance Test : } & & $\mathbf{6 , 0 2 4 , 5 5 4}$ \\
Plant Start Up & & \\
Working Capital & & 0.05 & 301,228 \\
& Total CAPEX & 0.1 & 602,455 \\
& & & $\mathbf{6 , 9 2 8 , 2 3 7}$
\end{tabular}

Perhitungan keekonomian dilakukan dengan model skema Cost Recovery KKKS (Kontraktor Kontrak Kerja Sama). Untuk perhitungan revenue menggunakan harga jual gas 4 US\$/MMBTU, kondensat 63,5 US\$/bbl. Perhitungan biaya operasi OPEX gas 1,7 US\$/MSCF dan minyak 17,5 US\$/bbl. Hasil keekonomian dengan umur produksi 10 tahun ditunjukan pada Tabel 6. sebagai berikut:

Tabel 6. Hasil Perhitungan Keekonomian

\begin{tabular}{lcc}
\hline \multicolumn{1}{c}{ Parameter } & Satuan & Hasil Kekonomian \\
\hline IRR & $\%$ & $348.19 \%$ \\
NPV@ $10 \%$ & US \$ Ribu & 132,020 \\
POT discounted & Year & 0.31 \\
PV Rasio & & 19.06 \\
\hline
\end{tabular}

Berdasarkan Tabel 6. menunjukan bahwa modifikasi penambahan peralatan chiller akan ada tambahan produksi gas dan kondensat sehingga menghasilkan gross revenue. Dengan menggunakan perhitungan keekonomian model skema cost recovery KKKS (Kontraktor Kontrak Kerja Sama) diperoleh nilai IRR sebesar 348,19\%, dengan tingkat diskon faktor 10\% didapatkan NPV US\$132.020.000, tingkat pengembalian investasi POT sebesar 0,31 tahun dan PV rasio sebesar 19,06. Dengan demikian indikator keekonomian NPV positif, IRR > dari suku bunga bank dan POT cepat serta PV rasio lebih dari 1. Sehingga dapat disimpulkan dengan modifikasi penambahan chiller ini secara teknoekonomi layak dilakukan untuk menaikan revenue perusahaan.

\section{KESIMPULAN}

Penelitian ini menggunakan perangkat lunak UNISIM telah berhasil melakukan simulasi pemodelan rekonstruksi aMDEA dengan menggunakan campuran amine yaitu fraksi berat MDEA 0,3618 dan MEA 0,088 dimana laju alir amine dan $\mathrm{CO}_{2}$ sesuai desain. Dengan model tersebut dilakukan analisa pengaruh tekanan dan suhu. Pengaruh tekanan gas umpan yang semakin rendah maka akan semakin tinggi kandungan $\mathrm{CO}_{2}$ dan $\mathrm{H}_{2} \mathrm{~S}$ dalam produk gas jual karena amine akan semakin volatile dan menurunnya tekanan parsial asam dalam gas umpan akibatnya menurunkan laju reaksi dengan amine. Sedangkan pengaruh suhu gas umpan semakin tinggi maka akan semakin tinggi kandungan $\mathrm{CO}_{2}$ dan $\mathrm{H}_{2} \mathrm{~S}$ dalam produk gas jual dan juga akan mengakibatkan foaming karena adanya kondensasi fraksi berat. Untuk optimasi dilakukan penurunan suhu gas umpan menjadi $60 \mathrm{~F}$ menggunakan chiller dengan mempertimbangkan suhu terbentuknya hydrate sehingga AGRU dapat beroperasi dengan laju alir gas umpan 83,7 MMSCFD dari semula 40 MMSCFD. Adanya kenaikan produksi gas jual sebesar 38,1 MMSCFD dan kondensat 1376 bpd. Modifikasi penambahan chiller diperlukan biaya CAPEX sebesar US\$ 6.928.237 dan hasil perhitungan keekonomian yang layak dengan parameter NPV US\$ 132.000.000, IRR 348,19\%, POT 0,31 tahun dan PV Rasio 19,06.

\section{DAFTAR PUSTAKA}

Abdi, M.A. (2016) Desain and operations of natural gas sweetening facilities. Course Prepared for Iranian Gas Company. Faculty of Engineering and Applied Science, Memorial University of Newfoundland (MUN).

Aliabad, H. Zare, Mirzaei, S. (2009) Removal of $\mathrm{CO}_{2}$ and $\mathrm{H}_{2} \mathrm{~S}$ using aqueous alkanolamine solutions. International Journal of Chemical and Biological Engineering 2:2.

Arkema Co. (2000) MDEA proven technology for gas treating systems. 
Bishnoi, S., Rochelle, J.T. (2002) Thermodynamics of piperazine / methyl diethanolamine/ water / carbon dioxide. The University of Texas at Austin, USA.

Bullin, J.A., Polasek, J.C. (1990) The use of mdea and mixtures of amines for bulk $\mathrm{CO}_{2}$ removal. Bryan Research \& Engineering, Inc., Bryan, Texas.

Chung-Sung, T. (2006) Absorption of carbon dioxide with piperazine and its mixtures in a rotating packed bed. Separat. Purif. Technol. Taiwan.

Garrett, Donald E. (2013) Chemical engineering economics. New York: Van Nostrand Reinhold, $16^{\text {th }}$ Edition.

Gas Processor Supplier Association. (1998) Engineering data book. Tulsa, Oklahoma, Eleventh Edition.

Ibrahim, A.Y, et al. (2014) Effect of piperazine on carbon dioxide removal from natural gas using aqueous methyl diethanol amine. Journal of Natural Gas Science and Engineering.

Kohl, A.L., Nielson, R.B. (1997) Gas purification. Houston: Gulf Publishing Company, Fifth ed.

Kolmetz, Karl. (2012) Natural gas sweetening systems selection, sizing and troubleshooting. Malaysia: KLM Technology Group.

Optimized Treating, Inc. (2008) Piperazine, why it's used and how it works. Vol. 2. Issue 4.

Pandey, M. (2005) Process optimization in gas sweetening unit-a case study. In: Proceedings of the International Petroleum Technology Conference, Doha, Qatar.

Park, J., et al. (2020) Improving energy efficiency for a low-temperature $\mathrm{CO}_{2}$ separation process in natural gas processing. Journal of Energy.

Polasek, John, Bullin, Jerry A. (2006) Selecting amines for sweetening units. Bryan, Texas: Research \& Engineering, Inc. 